\title{
EFFECT OF GENOTYPE, AGE AND SEASON ON HATCHABILITY OF EGG
}

\author{
S. S. Islam ${ }^{1}$, M. B. Hossain ${ }^{2}$ and M. K. A. Khan ${ }^{3}$
}

\begin{abstract}
The study was conducted to study the effects of genotype and age of hen and hatching season on hatchability of egg. Hatching eggs were collected from hens having three genotypes viz. White Leghorn (WLH), Rhode Island Red (RIR) and Fayoumi covering three age groups ( 28 to 40,41 to 60 and 61 weeks \& above) at winter, monsoon and summer seasons. The study revealed that the highest $(\mathrm{P}<0.05)$ average hatchability was observed in winter $(78.62 \%)$ followed by monsoon (76.70\%) and summer (75.79\%). Among different genotypes the highest $(\mathrm{P}<0.001)$ hatchability was found in Fayoumi $(78.34 \%)$ followed by White Leghorn $(76.48 \%)$ and Rhode Island Red $(74.59 \%)$. Considering the age of hen, highest $(\mathrm{P}<0.05)$ hatchability was found in the age group between 41 to 60 weeks $(77.99 \%)$ followed by 61 weeks and above $(76.49 \%)$ and 28 to 40 weeks $(75.71 \%)$ of age. From the findings it can be concluded that the winter season was suitable for hatching of eggs and the performance of Fayoumi hen was better in terms of hatchability of egg. On the other hand, the age of hen between 41 to 60 weeks was better for producing hatching eggs.
\end{abstract}

Key words : Season, Genotype, Age, Hatchability

\section{Introduction}

Fertility and hatchability are the most important determinant for producing more chicks from given number of breeding stock within a stipulated period. Fertility and hatchability performance of eggs depend on the number of factors like genetic, physiological, social and environmental (Jull, 1970). The principal objectives of the commercial hatchery are to secure the maximum number of quality day-old chicks out of the eggs set for hatching. Several researchers reported that genotype of breeder hen had significant effect on hatchability of egg (Jayaranjan, 1992; Islam et al., 2002). In another study significantly $(\mathrm{P}<0.05)$ higher hatchability was found in Desi and RIR hens compared to Fayoumi (Farooq et al., 2003). Significant effects of genotype and age of hen were also reported by Suarez et al. (1997). Das (1994) observed variation of hatchability in different age of breeder hens and reported maximum hatchability in the first laying year. Seasonal fluctuations could cause wide variability in hatchability. Higher hatchability of chicken eggs was reported in spring than in summer (Farooq et al., 2003). North (1984); Farooq et al. (2000) also reported poor hatchability in summer hatches. Chowdhury et al. (2004) also reported highest hatchability of duck eggs in winter and lowest in summer. The study was undertaken to observe the effects of genotype, age of hen and season on hatchability of eggs.

\footnotetext{
${ }^{1}$ Agrotechnology Discipline, Khulna University, Khulna, Bangladesh

${ }^{2}$ Scientific Officer, District Artificial Insemination Centre, Jessore, Bangladesh

${ }^{3}$ Animal Nutrition Section, Department of Livestock Services, Dhaka-1215, Bangladesh
}

(Received : March 29, 2008) 
Bang. J. Anim. Sci. 2008, 37 (1)

\section{Materials and Methods}

The study was conducted at Government Poultry Farm, Jessore. Hatching eggs were collected from breeder hens reared in the farm. Breeder hens belonged to three different genotypes viz. White Leghorn (WLH), Rhode Island Red (RIR) and Fayoumi. The breeder hens were categorized into three age groups such as age between 28 to 40,41 to 60 and 61 weeks and above to investigate the effects of age on the hatchability of eggs. Three seasons such as summer (March to June), monsoon (July to October) and winter (November to February) were considered throughout the year.

\section{Management of birds}

Breeder hens were reared in deep litter system. Average floor space allowed for each bird was $1.5 \mathrm{sq}$. $\mathrm{ft}$. Birds were vaccinated for Ranikhet Disease (BCRD), Gumboro, and Fowl Pox, Fowl Cholera diseases. One cock was maintained for every 10 breeder hens to obtain fertile eggs and one laying nest was provided for every 5 hens. All birds were fed ad libitum on diets containing $17 \%$ crude protein and $2800 \mathrm{Kcal} \mathrm{ME} / \mathrm{kg}$ diet. The ingredients of ration are mentioned in Table 1.

Table 1. Ingredients of ration for breeder hen

\begin{tabular}{|l|c|}
\hline \multicolumn{1}{|c|}{ Ingredients } & Quantity (\%) \\
\hline Wheat & 50.0 \\
Protein concentrate & 8.25 \\
Soybean meal & 18.0 \\
Rice polish & 17.0 \\
Oyster shell & 6.0 \\
Common slat & 0.50 \\
Vitamin mineral premix (Rhodivit BR) & 0.25 \\
\hline
\end{tabular}

\# Source : Rampart Power, Dhaka, Bangladesh

Egg collection and storage

Hatching eggs were collected twice daily and kept separately according to the genotypes of hen and date of collection. Good shaped and sound shelled eggs were selected for hatching purpose. Cracked, odd colored and other abnormal eggs were excluded. Dirty eggs were made clean by clean cloths. Hatching eggs were stored at $10^{\circ} \mathrm{C}$ and $75 \%$ of relative humidity for a period of 3 to 7 days.

\section{Incubation}

Eggs were hatched by electric incubator having the capacity of 43,000 eggs for setter and 22,000 eggs for hatcher. Before introducing new batch of hatching eggs, the incubator was cleaned and fumigated to prevent pathogenic infection. Fumigation was done using formaldehyde and potassium permanganate at the ratio of 45 and $30 \mathrm{~g}$, respectively for 100 cubic $\mathrm{ft}$. area. Setting and hatching temperature were 99 and $98^{\circ} \mathrm{F}$, respectively. Setting and hatching humidity were 75 and $80 \%$, respectively. The eggs were turned hourly automatically by programmed device. On the $7^{\text {th }}$ and $14^{\text {th }}$ days of incubation, the eggs were candled to identify and remove infertile eggs and eggs with dead embryos. The remaining eggs were transferred from setting trays to hatching trays on $19^{\text {th }}$ day of incubation. On $21^{\text {st }}$ day, hatched out chicks were collected and counted. Hatchability percentage was calculated by the number of chicks hatched divided by total number of eggs set and multiplied by 100 . 


\section{Statistical analysis}

Data were subjected to analysis of variance (ANOVA) with the help of a computer package program (SPSS, 1999). Least Significant Differences (LSD) test was performed to compare the significant differences among the means (Steel and Torrie, 1980).

\section{Results and Discussion}

\section{Effects of season}

Among different hatching seasons, the highest average hatchability (\%) was observed in winter $(78.62 \%)$ followed by monsoon $(76.70 \%)$ and summer $(75.79 \%)$ and the mean difference was significant $(\mathrm{P}<0.05)$ (Table 2). Significant effect of season on hatchability was also observed by Chowdhury et al. (2004). They found the highest hatchability of duck eggs in winter $(57.676 \%)$ followed by summer (54.135\%) and monsoon (49.134\%) respectively. In another study, seasons of the year had a significant effect on hatchability of chicken eggs, being higher in spring than in summer (Farooq et al., 2003). North (1984); Farooq et al. (2000) also reported poor hatchability in summer hatches. The higher hatchability during winter season in the present study could be attributed to favorable environment for egg storage and availability of more fresh eggs for hatching than in other seasons of the year. The decline in hatchability performance in summer may perhaps be attributed to pre-incubation development and weakening of the embryos before the eggs were received at the hatchery and with inactive breeding stock in hot weather. Jayaranjan (1992) also observed a significant effect of hatching season on hatchability. He found highest hatchability percentage in winter (68.09 \pm 4.83$)$ and lowest in summer (66.81 \pm 4.04$)$.

Table 2. Effects of hatching season on the hatchability of egg

\begin{tabular}{|l|l|c|c|c|}
\hline \multicolumn{1}{|c|}{ Parameters } & \multicolumn{1}{c|}{ Seasons } & No. of batch & Mean \pm SE & Level of significance \\
\hline \multirow{3}{*}{$\begin{array}{l}\text { No. of eggs set in } \\
\text { each batch }\end{array}$} & Monsoon & 28 & $3774.39 \pm 299.17$ & NS \\
& Winter & 27 & $4030.74 \pm 279.10$ & \\
\hline & Summer & 31 & $3704.03 \pm 279.06$ & $*$ \\
\hline \multirow{3}{*}{ Infertile eggs (\%) } & Overall & 86 & $3829.51 \pm 163.93$ & \\
& Monsoon & 28 & $23.30^{\mathrm{a}} \pm 2.79$ & \\
& Winter & 27 & $21.38^{\mathrm{b}} \pm 1.90$ & \\
\hline & Summer & 31 & $24.21^{\mathrm{a}} \pm 4.13$ & \\
\hline Hatchability (\%) & Overall & 86 & $23.02 \pm 3.32$ & $76.70^{\mathrm{b}} \pm 0.53$ \\
& Monsoon & 28 & $78.62^{\mathrm{a}} \pm 0.37$ \\
& Winter & 27 & $75.79^{\mathrm{b}} \pm 0.74$ \\
\hline & Summer & 31 & $76.97 \pm 0.36$ \\
\hline
\end{tabular}

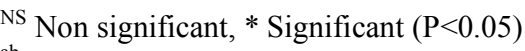

${ }^{\mathrm{ab}}$ Means with uncommon superscripts for each parameter differ significantly $(\mathrm{P}<0.05)$
} 
Bang. J. Anim. Sci. 2008, 37 (1)

\section{Effects of genotype}

The effects of genotypes on the hatchability of eggs is shown in Table 3. The highest mean hatchability was found in Fayoumi (78.34\%) followed by WLH (76.48\%) and RIR (74.59\%) respectively. The effects of genotypes on the hatchability was found significant $(\mathrm{P}<0.001)$. Significant effect of genotypes on hatchability was also observed by Islam et al. (2002). They found that hatchability of total eggs set as 91.28, 86.08, 79.57 and 84.95\% for Barred Plymouth Rock, WLH, RIR and White Rock, respectively. Farooq et al. (2000) and Murad et al. (2001) reported higher hatchability in Fayoumi chicken which is consistent with the present findings. However, Farooq et al. (2001) found that similar hatchability between of Fayoumi and Desi chicken of Pakistan. Significantly $(\mathrm{P}<0.05)$ higher hatchability was found in Desi and RIR hens compared to Fayoumi by Farooq et al. (2003) which corresponds well with the present findings. Jayaranjan (1992) found significant variation $(\mathrm{P}<0.05)$ in hatchability among genotypes. In his study the mean hatchability of White Rock, RIR and WLH were 68.89, 63.69 and 57.93\% respectively. The findings of the present study did not agree with that of Chaudhry and Alvi (1967) who found no significant difference in hatchability of fertile eggs between RIR and New Hampshire ( $\mathrm{P}>0.05)$. However, Reddy et al. (1965) found higher hatchability of eggs from WLH (66.80\%) than those of RIR (59.60) and White Rock $(44.10 \%)$ on total set eggs.

Table 3. Effects of genotypes of hen on the hatchability of egg

\begin{tabular}{|c|c|c|c|c|}
\hline Parameters & Genotypes & No. of batch & Mean \pm SE & Level of significance \\
\hline \multirow{4}{*}{$\begin{array}{l}\text { No. of eggs set in } \\
\text { each batch }\end{array}$} & Fayoumi & 37 & $4404.54^{\mathrm{a}} \pm 214.63$ & \multirow{3}{*}{$* *$} \\
\hline & WLH & 35 & $4013.43^{\mathrm{a}} \pm 225.50$ & \\
\hline & RIR & 14 & $1850.00^{\mathrm{b}} \pm 185.92$ & \\
\hline & Overall & 86 & $3829.51 \pm 163.93$ & \\
\hline \multirow{4}{*}{ Infertile eggs $(\%)$} & Fayoumi & 37 & $21.66^{\mathrm{b}} \pm 3.55$ & \multirow{3}{*}{$* *$} \\
\hline & WLH & 35 & $23.51^{\mathrm{a}} \pm 2.39$ & \\
\hline & RIR & 14 & $25.40^{\mathrm{a}} \pm 3.16$ & \\
\hline & Overall & 86 & $23.02 \pm 3.32$ & \\
\hline \multirow{4}{*}{ Hatchability (\%) } & Fayoumi & 37 & $78.34^{\mathrm{a}} \pm 0.58$ & \multirow{3}{*}{$* *$} \\
\hline & WLH & 35 & $76.48^{\mathrm{b}} \pm 0.40$ & \\
\hline & RIR & 14 & $74.59^{\mathrm{b}} \pm 0.85$ & \\
\hline & Overall & 86 & $76.97 \pm 0.36$ & \\
\hline
\end{tabular}

** Significant $(\mathrm{P}<0.01)$

${ }^{\mathrm{ab}}$ Means with uncommon superscripts for each parameter differ significantly $(\mathrm{P}<0.05)$

\section{Effects of age of hen}

Table 4 shows the effects of hen age on hatchability. Among three different age groups of breeder hen, the highest $(\mathrm{P}<0.05)$ hatchability was found in 41 to 60 weeks $(77.99 \%)$ and lowest in 28 to 40 weeks. Similarly, Das (1994) stated that age of breeder hen affects the hatchability. He reported that maximum hatchability has been observed in the eggs produced in the first laying year. Suarez et al. (1997) observed significant effect of age of hen at lay on hatchability, which is consistent with the present findings. 
Table 4. Effects of age of hen on the hatchability of egg

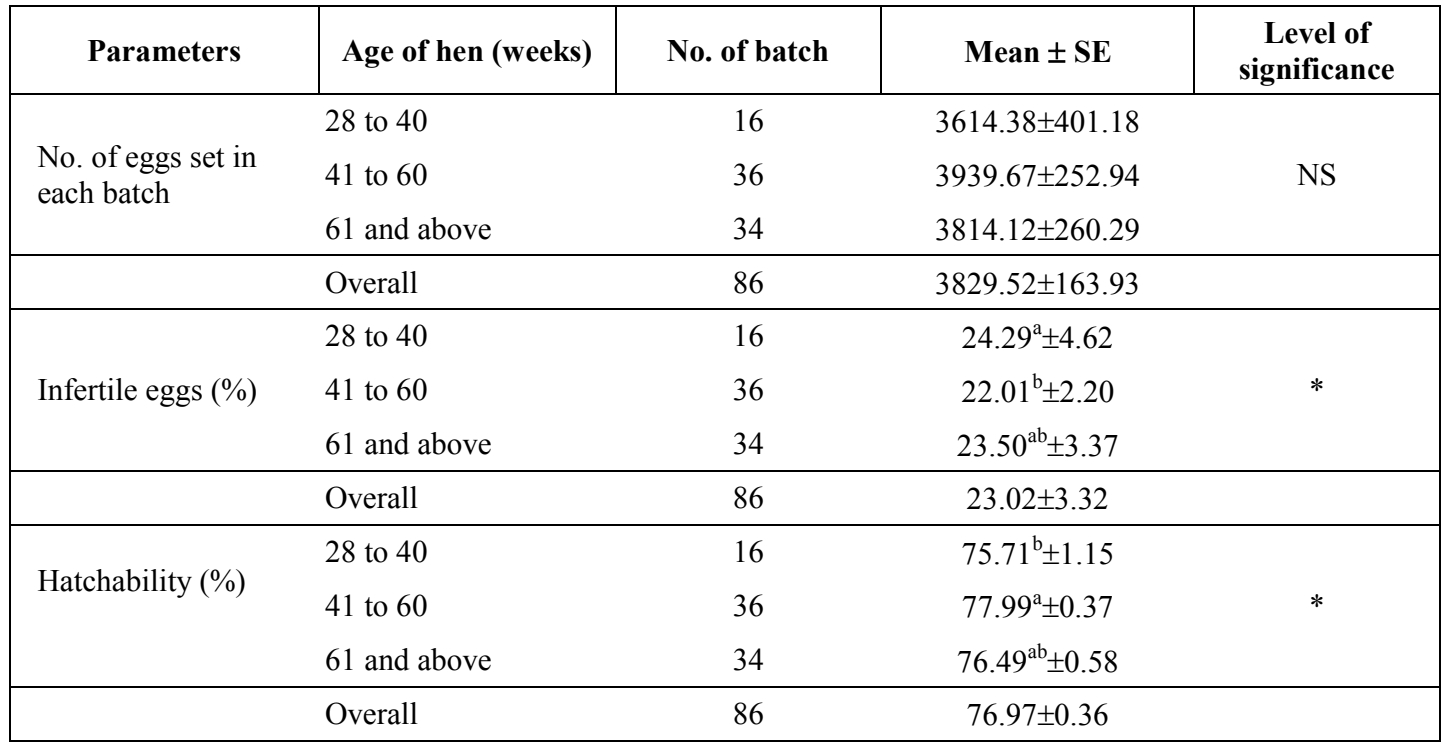

${ }^{\mathrm{NS}}$ Non significant, * Significant $(\mathrm{P}<0.05)$

${ }^{\mathrm{ab}}$ Means with uncommon superscripts for each parameter differ significantly $(\mathrm{P}<0.05)$

\section{Conclusion}

The results revealed that the winter season was the best time for higher hatchability under Bangladesh condition. Eggs from Fayoumi hens were found better for hatching purpose. On the other hand, age between 41 to 60 weeks was suitable for the production of hatching eggs.

\section{Literature Cited}

Chaudhry, M. R. and Alvi, M. S. 1967. Comparative study of fertility and hatchability of New Hampshire and Rhode Island Red breeds of chicken. Anim. Breeding Abstr. $39: 383$.

Chowdhury, M. M. I., Ashraf, A., Mondal, S. P., Mondol, N. M. A. A. M. and Hasan, M. M. 2004. Effect of season on the hatchability of duck eggs. International J. Poult. Sci. $2004: 3(6): 419-421$.

Das, S. K. 1994. Poultry Production, First edn., CBS Publishers and Distributors, Shahdara, Delhi, India, pp. 41.

Farooq, M., Durrani, F. R., Aleem, M., Chand, N. and Muqarrab, A. K. 2001. Egg traits and hatching performance of Desi, Fayoumi and Rhode Island Red Chicken. Pakistan J. Biol. Sci. 4 (7) : 909-911.

Farooq, M., Javed, K., Durrani, F. R., Irfanullah, K. and Chand, N. 2003. Hatching performances of backyard hens in Peshawar, Pakistan. Livest. Res. Rural Dev. 15 (9) : 1-7.

Farooq, M., Shoukat, K., Asrar, M., Mussawar, S., Durrani, F. R., Asghar, A. and Faisal, S. 2000. Impact of Female Livestock Extension Workers (FLEWs) on rural household chicken production in Mardan division. Livest. Res. Rural Dev. 12 (4) : 1-10. 
Bang. J. Anim. Sci. 2008, 37 (1)

Islam, M. S., Howlider, M. A. R., Kabir, F. and Alam, J. 2002. Comparative assessment of fertility and hatchability of Barred Plymouth Rock, White Leghorn, Rhode Island Red and White Rock Hen. International J. Poult. Sci. 1 (4) : 85-90.

Jayarajan, S. 1992. Seasonal variation in fertility and hatchability of chicken eggs. Indian J. Poult. Sci. 27 : 36-39.

Jull, M. A. 1970. Considerable progress achieved in breeding for increased egg production in Egypt. World Poult. Sci. J. 26 : 200-202.

Murad, A., Farooq, M., Mian, M. A. and Muqarrab, A. K. 2001. Hatching performance of Fayoumi eggs. Sarhad J. Agric. 17(1) : 1-6.

North, O. M. 1984. Egg storage and hatching, In: Commercial Chicken Production Manual. $3^{\text {rd }}$ ed. Avi Publishing company, Inc. Westport, Connecticut, pp. 77-78.

Reddy, V. B., Subbarayudee, D. and Varadarajulee, P. 1965. The effect of breed, pre-incubation storage time and egg weight on hatchability of Poultry. Anim. Breeding Abstr. $34: 268$.

SPSS. 1999. Statistical package for Social Sciences. User's Manual (Release 9.0). pp. 225-233.

Steel, R. G. R. and Torrie, J. H. 1980. Principles and Procedures of Statistics, $2^{\text {nd }}$ edition. Mc Graw-Hill Int. Book Co. New Delhi.

Suarez, M. E., Wilson, H. R., Mather, F. B., Wilcox, C. J. and Mcpherson, B. N. 1997. Effect of strain and age of the broiler breeder female on incubation time and chick weight. Poult. Sci. $76: 1029-1036$. 